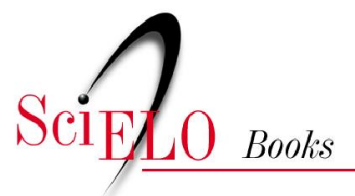

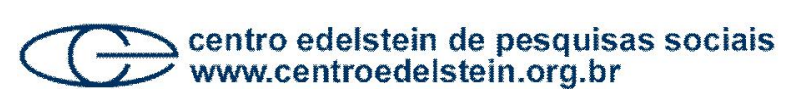

wWW.centroedelstein.org.br

\title{
Spain
}

\author{
Armando Albert
}

SciELO Books / SciELO Livros / SciELO Libros

ALBERT, A. Spain. In SORJ, B., CANTLEY, M., and SIMPSON, K., eds. Biotechnology in Europe and Latin America: prospects for co-operation [online]. Rio de Janeiro: Centro Edelstein de Pesquisas Sociais, 2010. pp. 107-112. ISBN: 978-85-7582-036-6. Available from SciELO Books $<$ http://books.scielo.org $>$.

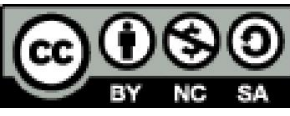

All the contents of this chapter, except where otherwise noted, is licensed under a Creative Commons Attribution-Non Commercial-ShareAlike 3.0 Unported.

Todo o conteúdo deste capítulo, exceto quando houver ressalva, é publicado sob a licença Creative Commons Atribuição Uso Não Comercial - Partilha nos Mesmos Termos 3.0 Não adaptada.

Todo el contenido de este capítulo, excepto donde se indique lo contrario, está bajo licencia de la licencia Creative Commons Reconocimento-NoComercial-CompartirIgual 3.0 Unported. 


\subsection{SPAIN}

Armando Albert

Biotechnology, understood as the application of the principles of science and engineering to the treatment of materials by means of biological agents, for the production of goods and services, comprises a wide field of study.

The economic and social importance is now unquestionable, especially if it is understood that in our country the production value of the potential users amounts to some 15\% of the Gross Domestic Product.

\section{Mobilising Programme}

Spain has a scientific community capable of incorporating biotechnology into its production systems, and into an improvement of its services. For this a series of objectives have been defined and the necessary economic resources for the Biotechnology Mobilising Programme have been made available. This Programme was initiated by the government in response to the perceived gap in the organisation and execution of biotechnology research and application. The situation was explained in the volume: 'Programa Movilizador de Biotecnologia', published by the Ministry of Science and Education in Rine 1985.

So far the execution of the Mobilising Programme has been satisfactory, with objectives being attained. The state has made funds available and no major contradictions in proposals and financial realities have emerged.

\section{Present Situation of the Biotechnology Sector}

More than 250 groups are working on biotechnology in the public sector (universities and government research laboratories) and nearly 50 firms have expressed an interest in biotechnology R\&D. The situation indicates sufficient activity to generate a biotechnological 'critical mass' in the near future. The response to the Mobilising Programme has been encouraging and early results are promising.

\section{STAFF TRAINING}

Spain supports over 100 research fellows. A further $80+$ fellows have spent at least one year in foreign centres.

CENTRO NACIONAL DE BioteCNOLOGia, CNB

Initiated in 1987 this centre should become fully operational this year, representing a total investment of about us $\$ 25$ million. Director, Michael Parkhouse has been appointed and recruitment of other senior staff is going on.

Fifty research projects are being financed in public sector laboratories, and a further 10 projects involving companies, with a total budget of about US\$8 million.

The research projects fall into the area of application orientated basic research. 18 studies are ongoing, 8 in genetic engineering, 9 in human and animal health, 9 in chemical and agro-food industry, 9 in Agriculture and 5 in biomass and pollution control.

Industrial projects focus upon aspects of human and animal health, the chemical industry and the food industry. The Centre for the Development of Industrial Technology, CDTI, has taken up the responsibility of supporting $20 \mathrm{R} \& \mathrm{D}$ programmes with a total value of about US\$30 million.

The conclusion of the Mobilising Programme has stimulated the view that it is necessary to continue and increase efforts in this area with a R\&D National Programme in Biotechnology, along the lines indicated below.

\section{Planned Actions}

The following major themes encapsulate the National Programme.

\section{Human Resources - Staff Training}

The Mobilisation Programme confirmed the need to increase efforts in training. During the five year period of the National Programme it is proposed to train a further 225 biotechnology $\mathrm{PhDs}$, and to send 100 to 150 scientists to foreign centres of excellence, with a view to covering deficiencies in areas such as: biochemical engineering, downstream processing, cell culture, etc. 
This effort must be accompanied by the establishment of relevant courses for specialist engineers and technicians. It is anticipated that the National Biotechnology Centre will play a decisive role in this training effort.

At least 100 scientists are going to be recruited into the public sector so as to reinforce Spanish biotechnology. At least 35 of these new posts will be in the CNB.

\section{Instrumentation and Utilities}

This part of the programme will concentrate on two actions:

Support for the acquisition of equipment and instruments of middle to high price for the $\mathrm{CNB}$ and other public sector laboratories.

Creation of regional centres of excellence in biotechnology, associated with the $\mathrm{CNB}$ and other public institutes in their scientific environment. Financing is expected to be a mixture of national and regional. The creation of at least five such regional centres is foreseen.

\section{Financing of $R \& D$ Projects}

According to needs identified and the scientific and technological possibilities, research and technology development will be supported, with emphasis on the following priority areas:

a) basic research in biotechnology (3 areas)

b) agro food and agro-industrial aspects (6 areas)

c) health (4 areas)

d) industrial technology (5 areas)

e) biodegradation and pollution control (3 areas)

Ninety projects in universities and public laboratories, and between 35 and 40 concerted $R \& D$ projects are expected to be partly financed by industry, over a three year period within the five years of the programme.

\section{International Relations}

The participation of public research centres in European Community programmes will be actively supported. Special fellowship programmes will be established for graduates speaking Spanish or from the same geographical area. In the CITED-D, the Research Programme related to the 500th anniversary of the discovery of America, a number of projects in biotechnology have been established with Latin American collaborators.

\section{National Biotechnology Centre}

The creation of a National Biotechnology Centre was one of the specific objectives of the Biotechnology Mobilising Programme. Designed to house some 300-350 scientists this Centre of Excellence will require solid support during the launch phase. Such support will be provided by the Mobilising Programme.

Such is the significance of this venture that it is best considered apart from other aspects of the Mobilising Programme, although of course it will interact with all parts of that Programme. Staff Training

STAFF TRAINING

The Centre should be able to commence training of high calibre staff by the middle of 1989, through the organisation of courses and specialised workshops. A graduate fellowship programme will be initiated at the outset, with due regard to the specific needs that must be met in Spain. In accordance with its international interest the National Centre of Biotechnology will have a specific programme of scholarships for graduates from Latin American and African countries. About 15 such scholarship places are envisaged.

In the early stages it is envisaged that senior staff will be supported by 4 Visiting Professors, 15 graduate technicians and engineers, 20 laboratory technicians and some 20 young postdoctoral scientists.

EQUIPMENT AND UTILITIES

During the launch phase some 400 million ptas will be required.

PROJECT FINANCING AND COLLABORATIVE RESEARCH WITH INDUSTRY

The National Biotechnology Centre is expected to participate on a competitive basis for projects and funds managed by either government or industry.

\section{Management}

The Mobilising Programme is to be managed by a Programme Committee consisting of scientists and technologists. They will take the 
responsibility of making proposals according to scientific merit, technological interest and economic practicability in the following areas:

1. Personnel selection for their training in Spain and in foreign centres of excellence;

2. Infrastructure endowment (utilities and equipment);

3. Selection and funding of research projects and contracts with industry after appropriate peer review procedures;

4. Evaluation and follow up of results obtained;

5. Modifications to the Programme in consultation with both academia and industry;

6. Temporary programming of the aforementioned actions and coordination with related programmes, especially those of the CDTI;

7. Direct promotion of $R \& D$ programmes of special interest not covered by existing recommendations.

\section{Priorities}

In accordance with the needs identified by the Programme Committee, taking into account the scientific and technological competence available in Spain the following fields will be promoted by the Programme:

General Interest:

- Development of systems for genetic manipulation in organisms of interest for biotechnology;

- Development of animal and plant cell cultures related to their potential applications in biotechnology;

- Development of enzymatic and other biochemical processes with potential biotechnological application.

Agriculture and Food Area:

- Genetic improvement in plant breeding:

- Nitrogen fixation;

- Improvement of fermentation processes (wines, dairy products, fermented drinks);

- Improved microbial starter cultures;

- Bioconversion of lignocellulose materials

- Pesticides.

Health Area:

- New generation antibiotics;

- Immunology: vaccines, diagnostics, antigens, allergens;

- Blood proteins;

- Peptides, proteins and enzymes.

Industrial Area:

- Microbial mining;

- Recovery of heavy metals;

- Organic acids;

- Bioconversion-bioreactors.

Biodegradation and Pollution Control:

- Residue and effluent biotransformation;

- Microbial ponds for water purification;

- Microbial purification of metal contaminated waters

Predicted Cost of the Programme

\begin{tabular}{|lccc|}
\hline Item & Millions of pesetas & Millions of ECU & \% of total cost \\
\hline Staff training & 1622 & 11.2 & 18 \\
Researchers and contracted personnel & 1380 & 9.5 & 15 \\
Infrastructure & 2000 & 13.8 & 22 \\
Projects & 1600 & 11.0 & 17.5 \\
R\&D industrial concertation & 2240 & 15.5 & 24.5 \\
Business plan, other expenses & 270 & 1.9 & 3 \\
Totals & 9112 & 62.9 & 100 \\
\hline Note: running costs (salaries, maintenance etc.) of the research system are not included in the \\
budgeting
\end{tabular}

